\title{
Technology Acceptance Model of Financial Technology in Micro, Small, and Medium Enterprises (MSME) in Indonesia*
}

\author{
Pupung PURNAMASARI ${ }^{1}$, Irena Paramita PRAMONO², Ria HARYATININGSIH ${ }^{3}$, \\ Shahifol Arbi ISMAIL ${ }^{4}$, Rohami SHAFIE ${ }^{5}$
}

Received: July 18, 2020 Revised: August 23, 2020 Accepted: September 10, 2020

\begin{abstract}
Seeing the existence of MSME needs that have still not been met although this sector is undeniably important in Indonesian economy, changes in community behaviour and the intensity of the use of technology in the community, financial technology (fintech) has a lot of potentials to become a part of the solution of the problem commonly faced by MSMEs. Therefore this research needs to be done to observe the potential of fintech in integrating MSMEs in terms of the application of technology and knowledge from the community related to fintech. By using Technology Acceptance Model, this research tries to understand the determinant factors of the fintech application used by MSME. Based on the research framework and model, path analysis method used in this research. This research uses primary data gathered by the questioner, which was distributed to MSME. From the analysis conducted, we can conclude that the external factors tested in this research could have an effect on the behaviour intention through perceived usefulness in MSME practice of financial technology. Large variation in MSME educational background, busineess age and size would become a challenge in promoting fintech application, therefore this finding suggests that fintech should be promoted by highlighting what benefits can be obtained by using fintech application.
\end{abstract}

Keywords: Fintech, MSME, Technology, Acceptance

JEL Classification Code: C12, F65, G26, G53

\section{Introduction}

Indonesia has a large number of internet users. According to the data from the social website report (Simon, 2020),

\footnotetext{
*Acknowledgements:

The authors would like to thank to University Islam Bandung and University Utara Malaysia for the support in this research.

${ }^{1}$ First Author. Lecturer, Accounting Department, Economic and Business Faculty, University Islam Bandung, Indonesia.

Email: p_purnamasari@yahoo.co.id.

${ }^{2}$ Corresponding Author. Lecturer, Accounting Department, Economic and Business Faculty, Universitas Islam Bandung, Indonesia [Postal Address: Jl. Tamansari No. 24-26 Bandung, West Java, Indonesia] Email: irena.paramita@gmail.com; irena.paramita@unisba.ac.id.

${ }^{3}$ Lecturer, Economic Department, Economic and Business Faculty, Universitas Islam Bandung, Indonesia.

Email: ria.haryatiningsih@unisba.ac.id.

${ }^{4}$ Lecturer, School of Accountancy, University Utara Malaysia, Malaysia. Email: arbi@uum.edu.my.

5Lecturer, School of Accountancy, University Utara Malaysia,

Malaysia. Email: rohami@uum.edu.my.

(c) Copyright: The Author(s)

This is an Open Access article distributed under the terms of the Creative Commons Attribution Non-Commercial License (https://creativecommons.org/licenses/by-nc/4.0/) which permits unrestricted non-commercial use, distribution, and reproduction in any medium, provided the original work is properly cited.
}

there were about 175.4 million internet users in Indonesia in January 2020 , this number of users increased by $17 \%$ from 2019 , meanwhile the internet penetration stood at $64 \%$. Also, Indonesia has recorded as one of the largest number of social media users in the world.. There were 160 million social media users and 338.2 mobile connections in Indonesia by January 2020 (Simon, 2020). Technology has impacted a lot of changes in the financial sector. One phenomenon of technological disruption in the financial sector is Financial Technology (Fintech).

Fintech has evolved as a result of changes in the lifestyle of the people. It is a result of involvement of technology in their daily activities. According to the research by Batunanggar (Batunanggar, 2019), Indonesia has the potential for rapid development of fintech. Fintech is basically a technology application in the finance industry which is expected to continue developing in the future, including its increased practice in Micro, Small, and Medium Enterprises (MSME).

MSME is clearlyone of the potential customes of fintech, therefore understanding MSME character which supports fintech application should be examined futher. Darma et al. (Darma et al., 2020) in his research stated that fintech has a lot of potential to increase the sustainability of 
MSMEs in the form of efficiency from operational aspects and the ease of its members to access the capital. Because while MSME plays an important role in finance, there are still some difficulties that MSME has to face including the limited market share and capital. Research by Khodakivska also confirms that the size of loans is a reasonable proxy for enterprise employees, sales, and assets (Khodakivska, 2012). Meanwhile, according to Burger et al. (Burger et al., 2015), there are still nearly 20 percent of firms reported credit constraint as the largest barrier to growth. Research by Burger et.al. also stated that Indonesia's MSME is less productive than large firms and most of the MSME do not take steps to expand their business and only focus to serve the local market. Sanyal et al. (Sanyal et al., 2020) stated that SMEs need easier access to credit and have to develop their business networks and marketing capabilities in order to grow internationally.

Contratry to these statements, different facts have emerged in the field, research by Asmarani and Wijaya found that fintech still has no significant effect on retail banks stock returns listed on the Indonesian stock exchange (Asmarani \& Wijaya, 2020). This research showed that fintech still has a small influence in Indonesia's financial industry. Nguyen, Dinh, \& Nguyen (Nguyen, Dinh, \& Nguyen, 2020) identified five challenges in developing fintech in the country which are legal corridor, infrastructure, fintech companies, customers and human resources.

Both fintech payment and fintech lending could provide solutions in financing and bringing efficiency to do a transaction, and it could also help MSMEs to expand their business since fintech also offers flexibility of payment. Fintech has an impact on the ease and practicality in the process of financial transactions and reduces costs that arise in the transaction process. Seeing the existence of MSME needs that have still not been met even though this sector is undeniably important in Indonesian economy, changes in community behaviour and the intensity of the use of technology in the community, fintech has a lot of potential to become a part of the solution of the problem commonly faced by MSMEs, both in marketing and financing. By using the Technology Acceptance Model (TAM) which was introduced by Davis (Davis, 1985) this study tries to understand the determinant factors of the financial technology application usied by the MSME.

\section{Literature Review}

\subsection{Micro, Small, And Medium Enterprises (MSME)}

MSME is the most influential sector in the Indonesia economy, simply because the number of MSME entrepreneurs are more than $99 \%$ of the total entrepreneurs, provides more than $97 \%$ employment, and contributes more than $57 \%$ of the total GDP (Kemenkop, 2017). Micro Small Medium Enterprises, consist of several categorizations which are micro-businesses which have maximum assets IDR 50 millions and sales turnover maximum IDR 300 million; Small businesses which have assets between IDR 50 million- IDR 500 million and sales turnover IDR 300 million to IDR 2,5 billion; and medium businesses which have assets between IDR 500 million- IDR 10 billion and sales turnover IDR 2,5 billion to IDR 50 billion (UU No. 20 Tahun 2008, 2008). Meanwhile, Khodakivska (Khodakivska, 2012) categorized MSME into several categorization, micro-enterprises have less than 10 employees, total assets less than $\$ 100.000$, and annual sales less than $\$ 100.000$. Small enterprises have 10 to 50 employees, total assets between $\$ 100.000$ to $\$ 3$ million, and annual sales between $\$ 100.000$ to $\$ 3$ million. Small enterprises have 50 to 300 employees, total assets between $\$ 3$ million to $\$ 15$ million, and annual sales from $\$ 3$ million to $\$ 15$ million.

\subsection{Financial Technology (Fintech)}

Fintech can be defined as a combination between financial services and technology, it transforms the business model from conventional business model into modern business model, where buying, selling, and borrowing and other types of transactions are no longer required to be done face to face. According to a research company called venture scanner, there are 16 types of fintech categories currently available (Ventures Scanner, 2019), namely 1) banking infrastructure, 2) research and data, 3) transaction security, 4) POS payment, 5) institutional transfer, 6) institutional investing, 7) business tools, 8) business lending, 9) personal finance, 10) retail investing, 11) equity financing, 12) crowdfunding, 13) digital banking, 14) consumer lending, 15) consumer payments, 16) payment backend.

Fintech in Indonesia is divided into two categories, which are fintech lending and fintech payment. Fintech lending or financial technology related to lending and borrowing activities is regulated by Otoritas Jasa Keuangan (OJK) as Indonesia's financial services authority. Whereas fintech payment or financial technology related to payments in Indonesia is regulated by Bank Indonesia (BI). As of September 30, 2019, 127 companies had been registered and licensed in the OJK. Among the fintech start-up companies registered with OJK, 8 of them are listed as Islamic fintech, 118 companies provide conventional fintech services and 1 company provides sharia and conventional fintech services. However, in addition to the fintech list published by the OJK, there are many more fintech lending platforms in Indonesia whose practice is better known as a mobile or online loan. 
This research was designed not just to focus on one type of fintech, instead this research wants to observe both types of fintech. However, in the field, we found an interesting fact that most of the participants were more familiar with fintech payment and had limited understanding of fintech lending.

\subsection{Technology Acceptance Model (TAM) and Previous Research}

The acceptance model of information technology has been developed along with the magnitude of technology development. There were several models developed in the past, the theory of reasoned action, the technology of acceptance model, the motivational model, the theory of planned behaviour, a combining model of the technology acceptance model and the theory of planned behavior, the model of PC utilization, the innovation diffusion theory, and the social cognitive theory. These model were developed because there was a need for an ideal measurement model, and there was a necessity to provide information about what factors which could influence the successful implementation of a new technology.

Evaluation of Accounting Information Systems has been widely developed. TAM is one of the models which is often used for the technology users acceptance testing. TAM was introduced by Davis in 1989 in his $\mathrm{PhD}$ thesis. There are two objectives described by Davis by using TAM, first is to improve the understanding of the user acceptance process. Secondly, TAM provides a theoretical basis for practical user acceptance testing. As time goes by, TAM continues to develop, Lee, Kozar, and Larsen (Lee, Kozar, \& Larsen, 2003) stated that during the 18 years after TAM was introduced, it has made progress which could be divided into four periods, which are the introduction period, validation, extension, and elaboration. When this model was introduced for the first time, there were two variables which had an effect over the attitude towards using it, which were Perceived Usefulness (PU) and Perceived Ease of Use (PEOU). Now another variable called Attitude Toward Using (ATU) has emerged which also affects actual system use.

The second period was the validation period for TAM, which proved that this model was powerful, consistent, reliable, and valid. The third period was the extension period in which there were expansions with external variables such as individual, organizational, and task characteristics. The third period was a model elaboration period, which uncovered determinants like PEOU and PU.

TAM was used to study internet technology acceptance by consumers in 2004 (Gardner \& Amoroso, 2004). In this research, the researchers included external variables such as gender, experience, complexity and voluntariness to predict PEOU and PU. Luarn and Lin (Luarn \& Lin, 2005) used
TAM to predict users intentions to adopt mobile banking systems, which concluded that TAM could be used to predict users intentions to adopt mobile banking. Meanwhile, Rafique et al. (Rafique et al., 2020) explored the Acceptance of Mobile Library Application (MLA) with the technology acceptance model (TAM) as the basis model. In this research, the researcher added habit and system quality besides PEOU and PU as independent variables. Zhou, Dai, and Zhang (Zhou, Dai, \& Zhang, 2007) used TAM as the development of Online Shopping Acceptance Model (OSAM) to explain consumer acceptance of online shopping. In this research, the researcher concludes that consumer demographic and internet experience could have an effect on online shopping intention.

There are 5 latent variables in this research, which consist of external factors, Perceived Usefulness (PU), Perceived Ease Of Use (PEOU), Attitude Toward using (ATU), and Behaviour intention (BI). First latent variable is external factors, in this research, the external factors are outside business factors which could have an effect on the technology acceptance model of the MSME. The indicators in this research are the level of education of the entrepreneurs, business age which shows the length of time that the business has operated, business size of the MSME which is indicated by its assets.

Second latent variable is Perceived Usefulness (PU). Perceived usefulness is the degree of consumer belief in technology helpfulness according to Davis (1989). Similar to that, according to Alsamydai, PU is the degree of individual belief that they would receive benefit from using the new technology (Alsamydai, 2014). Perceived usefulness can be measured by how this technology could improve MSME performance, increase MSME productivity, increase effectiveness, make easier transactions, and be helpful for MSME.

Third latent variable is the Perceived Ease Of Use (PEOU). According to Nunkoo, Juwaheer, \& Rambhunjun, PEOU is the degree a person believes that using a technology would be free from any effort (Nunkoo, Juwaheer, \& Rambhunjun, 2013). This research uses indicators such as easiness to study, to understand, to use, to download/access, and also easiness in administrative usage could represent this variable.

Fourth variable is the Attitude toward using (ATU). The definition of attitude toward using refers to the positive or negative feeling evaluations generated when an individual uses new technologies, according to Chuang, Liu, and Kao (Chuang, Liu, \& Kao, 2016), happiness to use, enjoy to use, and boredom to use.

Fifth variable is the Behaviour intention (BI). Behavioural intention could be interpreted as the degree of a person's willingness to use a new technology, this definition is similar 
with the definition of behaviour intention mentioned by Bamberg, Ajzen, and Schmidt (Bamberg, Ajzen, \& Schmidt, 2003) which refers BI as an individual willingness to use the technology. In this research, we use indicators such as willingnes of the user to use it anytime, the intention to share the knowledge about the technology to other people, user willingness to use the technology, and user intention to continue using the technology.

\subsection{Proposed Model and Hypothesis Development}

This research is based on Technology Acceptance Model (TAM) which was developed by Davis (1989) and consists of 5 latent variables which are external factors, Perceived Usefulness (PU), Perceived Ease Of Use (PEOU), Attitude Toward Using (ATU) and Behaviour Intention (BI). The research model in this study is illustrated in Figure 1:

According to Zhou et al. (Zhou et al., 2007), it is explained that there is a positive relationship between consumers' age and their tendencies to purchase products online, it may happen because of the familiarity with using technology. Bagchi and Mahmood (Bagchi \& Mahmood, 2006) also found that online shops have a tendency to earn more money than the traditional stores because the most popular items are purchased online, and an increase in demand leads to an increase in the income. Research from Susskind (Susskind, 2017) identified a positive relationship between a person's education, time spending and money spending on online shopping. In this research, we use the level of education, business age and business size as the external factors. Therefore these variables are expected to have a significant effect on PU and PEOU of financial technology usage, and we can summarize the hypotheses as follows:

H1: External factors have a significant effect on PEOU on financial technology practice by MSME

H2: External factors have a significant effect on PU on financial technology practice by MSME
Davis (1989) stated that PEOU is possibly a causal antecedent to perceived usefulness. This was also confirmed by Chuang et al. (Chuang et al., 2016), Alsamydai (Alsamydai, 2014), and Nunkoo et al. (Nunkoo et al., 2013). Nunkoo et al. (2013) also stated that there is a positive relationship between perceived usefulness and intention towards online purchasing of products for tourism and traveling. Thus, the following hypotheses are proposed:

H3: PEOU has a significant effect on $P U$ on financial technology practice by MSME

H4: PEOU has a significant effect on ATU on financial technology practice by MSME

Research about perceived usefulness (PU) showed that this latent variable significantly correlated with usage behaviour and ease of use (Davis, 1989; Nunkoo et al., 2013). While Chuang et al. (Chuang et al., 2016) also concluded that perceived usefulness has a significant effect on attitudes toward using. This was also confirmed by Koufaris (Koufaris, 2002) which stated that perceived usefulness was an important determinant of intended system usage. Thus, the following hypotheses are proposed:

H5: PU has a significant effect to ATU on financial technology practice of MSME

H6: PU has a significant effect to BI on financial technology usage byMSME

Attitude Toward Using (ATU) known from Chuang et al. (Chuang et al., 2016) has a positive effect on BI in financial technology. This also fitted the result deducted by Davis (Davis, 1989) and Alsamydai (Alsamydai, 2014).
H7: ATU has significant effect to BI on financial technology practice by MSME

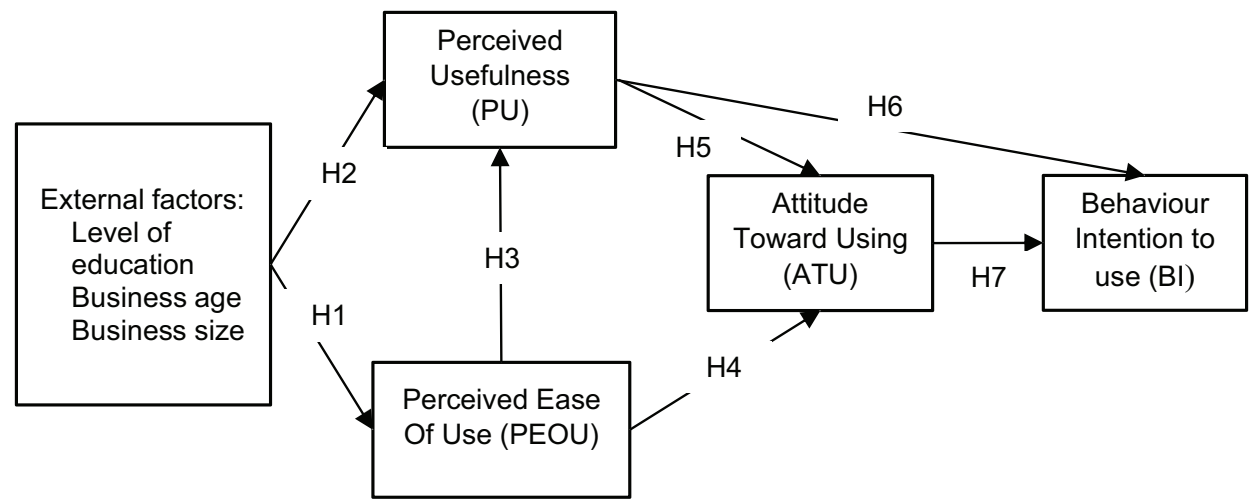

Figure 1: Technology Acceptance of MSME on Financial Technology Hypothesized Model 


\section{Research Methodology}

The approach we used in this research is the quantitative approach. The research method used in this research study, based on the research framework and model is path analysis. The software we used is WarpPLS software. This research uses primary data gathered by the questioner,which was distributed to MSME in Bandung, West Java area.

To have a complete answer, therefore in this research, we used 74 samples from MSMEs which were spread across in the Bandung area. According to Riadi (Riadi, 2018), to determine the SEM sample size, its range should be from 5 to 20 times the number of parameters used in the model. There are 7 parameters in this research model, based on that description the amount of the sample could range between 35 to 140 samples. Therefore 74 samples could be considered as sufficiently qualified in this model. Those variable indicators for perceived usefulness, perceived ease of use, attitude toward using, and behaviour intention assessed using questionnaire items measured on a 5-point scale in terms of how strongly the respondents felt about a set of statements from strongly agree to until strongly disagree. The table below presents the descriptive analysis of MSME participants profiles used in this research:

From the questioners, the researcher then performed validity and reliability analysis. Reliability analysis was performed using Cronbach Alpha test. Validity test performed by conducting bivariate correlations between each indicator score with the construct score. And according to the test, all of the construct variables passed the validity test.

\section{Result and Analysis}

\subsection{Validity and Reliability Test}

Reliability test conducted by Cronbach Alpha test, according to that test, all of the indicator variables in this questionnaire are reliable because it has Cornbach Alpha value more than 0.70 according to Nunnaly in Ghazali (2018). Here is the summary of the cronbach alpha test for every indicator variables:

Table 1: Descriptive Statistics of Participants

\begin{tabular}{|c|c|c|c|c|c|}
\hline \multicolumn{2}{|c|}{ Business Age } & \multicolumn{2}{|c|}{ Education Level } & \multicolumn{2}{|c|}{ Business Assets } \\
\hline Categories & Percentage & Categories & Percentage & Categories & Percentage \\
\hline$<1$ year & $23 \%$ & Primary school & $5.4 \%$ & $0-20$ millions & $54.1 \%$ \\
\hline $1-2$ years & $28.4 \%$ & Junior High School & $5.4 \%$ & 20-50 millions & $14.9 \%$ \\
\hline $3-4$ years & $14.9 \%$ & Senior High School & $44.6 \%$ & 50-100 millions & $8.1 \%$ \\
\hline 5-6 years & $13.5 \%$ & Diploma & $27 \%$ & $>100$ millions & $18.9 \%$ \\
\hline$>6$ years & $20.3 \%$ & Undergraduate & $14.9 \%$ & & \\
\hline & & Post Graduate & $1.4 \%$ & & \\
\hline
\end{tabular}

Table 2: Cornbach Alpha Value of Indicator Variables

\begin{tabular}{|l|c|c|}
\hline \multirow{4}{*}{ Perceived Usefulness (PU) } & PU1 & 0.864807 \\
\cline { 2 - 3 } & PU2 & 0.851949 \\
\cline { 2 - 3 } & PU3 & 0.849205 \\
\cline { 2 - 3 } & PU4 & 0.858099 \\
\cline { 2 - 3 } & PU5 & 0.873178 \\
\cline { 2 - 3 } & PU6 & 0.871661 \\
\hline \multirow{4}{*}{ Perceived Ease of Use (PEOU) } & PEOU1 & 0.917489 \\
\cline { 2 - 3 } & PEOU2 & 0.902429 \\
\cline { 2 - 3 } & PEOU3 & 0.897577 \\
\cline { 2 - 3 } & PEOU4 & 0.919174 \\
\cline { 2 - 3 } & PEOU5 & 0.930105 \\
\hline \multirow{3}{*}{ Attitude Toward Using (ATU) } & ATU1 & 0.783973 \\
\hline & ATU2 & 0.724138 \\
\cline { 2 - 3 } & ATU3 & 0.895738 \\
\cline { 2 - 3 } & BI1 & 0.817366 \\
\cline { 2 - 3 } & BI2 & 0.792857 \\
\cline { 2 - 3 } & BI3 & 0.787909 \\
\cline { 2 - 3 } & BI4 & 0.831684 \\
\cline { 2 - 3 } & &
\end{tabular}


Validity test in this research was conducted using bivariate correlations between each indicator score with the total construct score, and the result showed that all of the indicator variables are significant to the total construct score.

\subsection{Evaluation of Structured Model}

Evaluation of structural models includes a model fit test of path coefficient and $\mathrm{R}^{2}$. Model fit test results in this study indicate that the ten criteria described in the table below have been met, so it can be concluded that this study has met the requirements of model fit and it demonstrates a good fit between the model and the data.

\subsection{Data Analysis}

Software WrapPLS are used in this data analysis, There are 5 latent variables in this research, which are external factors, perceived usefulness, perceived ease of use, attitude toward using and behaviour intention. Meanwhile for the external factors which are level of education consist of 6 levels of education from primary high school until postgraduate level, for business age consists of 5 levels of time, which are from less than 1 year until more than 6 years. For business assets, it consists of 4 levels of categories which are from IDR 0-20 million until more than IDR 100 million. Here is the result of path analysis based on this model:

From Figure 2, which is the result of the process using WarpPLS, it is known that the $\mathrm{R}^{2}$ of the model is 0.44 or $44 \%$ which means that all of the variables in the model which consists of external factors, perceived usefulness, perceived ease of use, and attitude toward using affect behavioural intention to use financial technology by $44 \%$. Here is the conclusion based on Figure 2. From the path analysis conducted, we can conclude that from 7 hypotheses which were provided, there are 5 hypotheses which are accepted and 2 hypotheses are not accepted.

\section{Discussion}

First hypothesis test about external factors and PEOU showed that there is no significant effect on external factors to PEOU because the P-value is more than 0.05 as the degree of confidence was determined at $95 \%$. It means that the external factors of the MSME which performed in this research by the level of education of the entrepreneurs, business age and business size as the indicators do not have a significant effect on perceived ease of use (PEOU) simultaneously. This could have happened because the manual of an explanation of the financial technology usage could be accessed freely without the limitation of education, business age and business size. This result aligns with Bagchi and Mahmood (Bagchi \& Mahmood, 2006), which stated that there is no positive correlationbetween education and online spending.

On the other side, in the second hypothesis test about external factors and perceived usefulness (PU), there is a significant effect on the external factors to the perceived usefulness since the P-value is 0.02 which is less than 0.05 or $5 \%$. This result shows that the degree of belief that using financial technology could be beneficial is strongly affected by the level of education of the entrepreneurs, business age and business size. This result is in accordance with the previous hypothesis and the research by Bagchi and Mahmood (Bagchi \& Mahmood, 2006), which explained that there is a relationship between business size and online or offline store, meanwhile Susskind (Susskind, 2017) also identified that there is a relationship between education and the time and money spent on online shopping due to the familiarity with the technology.

Table 3: Model Fit and Quality Indices

\begin{tabular}{|l|c|c|c|c|}
\hline Information & Index & P-Value & Criteria & Result \\
\hline Average pathcoefficient (APC) & 0.344 & $P<0.001$ & $p<0.05$ & Acceptable \\
\hline Average R-squared (ARS) & 0.323 & $P<0.001$ & $p<0.05$ & Acceptable \\
\hline Average adjusted R-squared (AARS)=. P= & 0.308 & $P<0.001$ & $p<0.05$ & Acceptable \\
\hline Average block VIF (AVIF) & 1.347 & Acceptable if $<=5$. ideally $<=3.3$ & Acceptable \\
\hline Average full collinearity VIF (AFVIF) & 1.724 & Acceptable if $<=5$. ideally $<=3.3$ & Acceptable \\
\hline Tenenhaus GoF (GoF) & 0.465 & small $>=0.1$. medium $>=0.25$. large $>=0.36$ & Large \\
\hline Sympson's paradox ratio (SPR) & 1 & Acceptable if $>=0.7$. ideally $=1$ & Acceptable \\
\hline R-squared contribution ratio (RSCR)= & 1 & Acceptable if $>=0.9$. ideally $=1$ & Acceptable \\
\hline Statistical suppression ratio (SSR) & 1 & Acceptable if $>=0.7$ & Acceptable \\
\hline Nonlinear bivariate causality direction ratio (NLBCDR) & 0.857 & Acceptable if $>=0.7$ & Acceptable \\
\hline
\end{tabular}




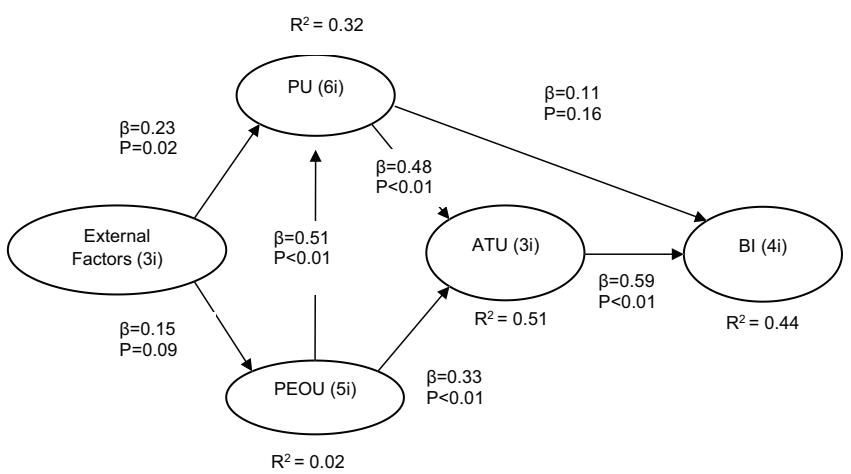

Figure 2: TAM analysis result

Table 5: Hypotheses Testing Result

\begin{tabular}{|l|c|c|c|}
\hline $\begin{array}{l}\text { Path } \\
\text { Analysis }\end{array}$ & P-value & $\begin{array}{c}\text { Significant } \\
\text { or Not } \\
\text { significant } \\
\text { (criteria } \\
\mathbf{P}<\mathbf{0 . 0 5 )}\end{array}$ & $\begin{array}{c}\text { Hyphothesis } \\
\text { Results }\end{array}$ \\
\hline $\begin{array}{l}\text { External } \\
\text { factors to } \\
\text { PEOU }\end{array}$ & 0.09 & Not significant & Rejected \\
\hline $\begin{array}{l}\text { External } \\
\text { factors to PU }\end{array}$ & 0.02 & Significant & Accepted \\
\hline PEOU to PU & $<0.01$ & Significant & Accepted \\
\hline $\begin{array}{l}\text { PEOU to } \\
\text { ATU }\end{array}$ & $<0.01$ & Significant & Accepted \\
\hline PU to ATU & $<0.01$ & Significant & Accepted \\
\hline PU to BI & 0.16 & Not significant & Rejected \\
\hline ATU to BI & $<0.01$ & Significant & Accepted \\
\hline
\end{tabular}

Meanwhile, for the third hypothesis test shows that PEOU variable has a significant effect on PU since its $\mathrm{P}$-value is less than 0.01 , it is aligned with the initial hypothesis and research by Davis (Davis, 1989) which stated that PEOU is causal antecedent to perceived usefulness. The fourth hypothesis test shows that PEOU has a significant effect on ATU since its P-value is less than 0.01 and it is similar with the initial research by Chuang et al. (Chuang et al., 2016), which clearly stated that PEOU has a significant positive effect on attitudes toward using.

For the fifth hypothesis test, it also shows the same result as the previous hypothesis since its P-value is less than 0.01 , and it shows that perceived usefulness (PU) has a significant effect to attitude toward (ATU) using which is similar with the conclusion from Chuang et al. (Chuang et al., 2016), which found that perceived usefulness has a significantly positive effect on attitudes toward using this technology. Meanwhile for the sixth hypothesis test about perceived usefulness and behaviour intention to use, showed that there is no significant effect on perceived usefulness to behaviour intention to use because the P-value is more than 0.05 or $5 \%$. This result means that the degree of consumer belief in technology helpfulness does not directly affect the individual willingness to perform, to use financial technology. Instead, it has an effect on the attitude toward using or to the positive or negative feeling evaluations generated when an individual uses new technologies, which indirectly affects the behaviour intention to use the financial technology. It is aligned with Septiani et al. (Septiani et al., 2018), which using TAM for Gojek behavioural intention to use by customer. For the seventh hypothesis test, it shows that attitude toward using affect behaviour intention in fintech using, which is similar with Chuang et al. (Chuang et al., 2016), which found that ATU has a positive effect on behavioural intention, and this result also fits with the research result performed by Davis (Davis, 1989) and Alsamydai (Alsamydai, 2014).

Looking at the various educational background of MSME business actors in Indonesia, large diversity in business age and assets, this research findings suggest that fintech should be promoted to MSMEs by highlighting what benefits that can be obtained by using fintech application because this could affect the behavioural intention of the MSME to use fintech application.

\section{Conclusion}

In conclusion, TAM is a solid model to test the determinant factors of financial technology using in MSME and through this model, we can conclude that the external factors tested in this research which are level of education, business age and size could affect the behaviour intention through perceived usefulness in MSME practice of financial technology.

\section{Limitations and Future Research}

In this research, we do not test individually about each external factor so we can not understand which external factor does not affect perceived usefulness, perceived ease of use and vice versa. Therefore it has to be further investigated in the future. And for improving the quality of the data, future research could use a bigger amount of data and a wider distribution of questionnaires.

\section{References}

Alsamydai, M. J. (2014). Adaptation of the Technology Acceptance Model (TAM) to the Use of Mobile Banking Services. International Review of Management and Business Research, 3(4), 20-39.

Asmarani, S. C., \& Wijaya, C. (2020). Effects of Fintech on Stock Return: Evidence from Retail Banks Listed in Indonesia 
Stock Exchange. Journal of Asian Finance, Economics and Business, 7(7), 95-104. https://doi.org/10.13106/jafeb.2020. vol7.no7.095

Bagchi, K., \& Adam, M. (2006). A longitudinal study of a business model of on-line shopping behavior using a latent growth curve approach. AMCIS 2006 proceedings, 240.

Bamberg, S., Ajzen, I., \& Schmidt, P. (2003). Choice of Travel Mode in the Theory of Planned Behavior: The Roles of Past Behavior, Habit, and Reasoned Action. Basic and Applied Social Psychology, 25(3), 175-187. https://doi.org/10.1207/ S15324834BASP2503_01

Batunanggar, S. (2019). Fintech Development and Regulatory Frameworks in Indonesia. Asian Development Bank Institute, (1014), 1-12.

Burger, N., Chazali, C., Gaduh, A., Rothenberg, A. D., Tjandraningsih, I., \& Weilant, S. (2015). Reforming Policies For Small And Medium-Sized Enterprises In Indonesia. Retrieved from www.tnp2k.go.id

Chuang, L., Liu, C., \& Kao, H. (2016). The Adoption of Fintech Service: TAM perspective. International Journal of Management and Administrative Sciences, 3(7), 1-15.

Darma, D. C., Kadafi, M. A., \& Lestari, D. (2020). FinTech and MSMEs Continuity: Applied in Indonesia. [Indonesian]

Davis, F. D. (1985). A technology acceptance model for empirically testing new end-user information systems: Theory and results. Doctoral dissertation, Massachusetts Institute of Technology.

Davis, F. D. (1989). Perceived usefulness, perceived ease of use, and user acceptance of information technology. MIS Quarterly, 13(3), 319-340. DOI: $10.2307 / 249008$

Gardner, C., \& Amoroso, D. L. (2004). Development of an instrument to measure the acceptance of internet technology by consumers. Proceedings of the Hawaii International Conference on System Sciences, 37(C), 4143-4152.

Ghazali, I. (2018). Multivariate Analysis Application with the IBM SPSS 25 Program (8th ed.). Semarang, Indonesia: Undip Publishing Agency.

Kemenkop. (2017). Data on the development of micro, small, medium and large enterprises in 2016 - 2017. Retrieved from http:/www.depkop.go.id/uploads/laporan/1549946778_ UMKM2016-2017 rev.pdf

Khodakivska, A. (2012). Measuring jobs from micro, small, and medium-size enterprises financed by IFC client financial institutions. IFC Client Financial Institutions., 1-3. Retrieved from www.ifc.org/jobcreation

Liu, S. H., Liao, H. L., \& Peng, C. J. (2005). Applying the technology acceptance model and flow theory to online e-learning users' acceptance behavior. E-learning, 4(H6), $\mathrm{H} 8$.

Lee, Y., Kozar, K. A., \& Larsen, K. R. T. (2003). The Technology Acceptance Model: Past, Present, and Future. Communications of the Association for Information Systems, 12. https://doi. org/10.17705/1 cais. 01250

Luarn, P., \& Lin, H. H. (2005). Toward an understanding of the behavioral intention to use mobile banking. Computers in Human Behavior, 21(6), 873-891. https://doi.org/10.1016/j. chb.2004.03.003

Nguyen, D. D., Dinh, H. C., \& Nguyen, D. Van. (2020). Promotion of Fintech Application for the Modernization of Banking-Finance System in Vietnam. Journal of Asian Finance, Economics and Business, 7(6), 127-131. https://doi.org/10.13106/jafeb.2020. vol7.no6.127

Nunkoo, R., Juwaheer, T. D., \& Rambhunjun, T. (2013, June). Applying the extended technology acceptance model to understand online purchase behavior of travelers. In: Proceedings of 21st international business research conference (pp. 10-11).

Rafique, H., Almagrabi, A. O., Shamim, A., Anwar, F., \& Bashir, A. K. (2020). Investigating the Acceptance of Mobile Library Applications with an Extended Technology Acceptance Model (TAM). Computers and Education, 145, 103732. https://doi. org/10.1016/j.compedu.2019.103732

Riadi, E. (2018). Statistik SEM structural equation modeling with Lisrel. Yogyakarta, Indonesia: CV Andi Offset.

Sanyal, S., Hisam, M. W., \& Baawain, A. M. S. (2020). Challenges facing internationalization of smes in emerging economies: A study on oecd model. Journal of Asian Finance, Economics and Business, 7(2), 281-289. https://doi.org/10.13106/jafeb.2020. vol7.no2.281

Septiani, R., Handayani, P. W., \& Azzahro, F. (2017). Factors that affecting behavioral intention in online transportation service: Case study of GO-JEK. Procedia Computer Science, 124, 504512.

Simon, K. (2020). Digital 2020: Indonesia. Retrieved July 10, 2020, from https://datareportal.com/reports/digital-2020indonesia

Susskind, A. M. (2017). Electronic Commerce and World Wide Web Apprehensiveness: an Examination of Consumers' Perceptions of the World Wide Web. Journal of Computer-Mediated Communication, 9(3). https://doi. org/10.1111/j.1083-6101.2004.tb00287.x

UU No. 20 Tahun 2008. (2008). UU No. 20 Tahun 2008. UU No. 20 Tahun 2008, (1), 1-31.

Ventures Scanner. (2019). Financial Technology Report Highlights - Q3 2019. Retrieved from https://www. venturescanner.com/2019/10/08/financial-technology-reporthighlights-q3-2019/

Zhou, L., Dai, L., \& Zhang, D. (2007). Online shopping acceptance model-A critical survey of consumer factors in online shopping. Journal of Electronic Commerce Research, 8(1), 41-63. 